\title{
PERAN KEBIJAKAN DIVIDEN DALAM MEMODERASI HUBUNGAN RASIO KEUANGAN DENGAN NILAI PERUSAHAAN
}

\section{Putria Hasfadillah $^{1 *}$, Yusralaini Yusralaini ${ }^{2}$, Devi Safitri ${ }^{3}$}

${ }^{123}$ Program Studi Akuntansi, Fakultas Ekonomi dan Bisnis, Universitas Riau, Pekanbaru

*E-mail: phasfadillah@gmail.com

\begin{tabular}{l} 
Keywords \\
\hline Corporate's Value \\
Dividend Policy \\
Liquidity \\
Profitability \\
Solvency \\
\hline
\end{tabular}

\begin{tabular}{l} 
Article information \\
\hline Received: \\
2020-01-27 \\
Accepted: \\
2020-02-11 \\
Available Online: \\
2020-02-25
\end{tabular}

\begin{abstract}
The purpose of this research was to analyze the effect of financial ratio on corporate value with dividend policy as moderation. Population on this research is all companies listed in Indonesia Stock Exchange (IDX) year 2015-2017. 108 companies selected using the purposive sampling method. Financial ratio used variable liquidity, solvency and profitability. The analysis method of this research is moderate regression analysis (MRA) by using SPSS 25 version. The result of this research shows that: liquidity has no significant effect on the corporate value, solvency and profitability has significant effect on the corporate value. Dividend policy has moderated relationship solvency and profitability with corporate value.
\end{abstract}

\section{PENDAHULUAN}

Perusahaan yang bergerak pada berbagai bidang seperti jasa, manufaktur, dagang maupun perbankan saling bersaing untuk dapat bertahan dan berlomba dalam menampilkan nilai terbaik perusahaan. Memenuhi kebutuhan pemegang saham merupakan tuntutan untuk perusahan agar perusahaan tersebut tetap berlangsung. Sebuah perusahaan yang telah dan akan berdiri harus memiliki tujuan yang jelas. Tujuan utama perusahaan adalah meningkatkan nilai perusahaan setiap periode dalam jangka panjang. Dalam Chowdhury dan Chowdhury (2010), menurut Modligani dan Mill (1963) bahwa nilai perusahaan adalah fungsi peningkatan leverage karena pengurangan pajak pembayaran bunga di tingkat perusahaan. Setelah itu, upaya akademis yang sangat besar telah dilakukan untuk mengidentifikasi biayabiaya yang relevan terkait dengan pembiayaan utang yang mungkin ditukar oleh perusahaan dengan manfaat pajak perusahaan yang besar ini. 
Meskipun biaya kebangkrutan langsung mungkin kecil, faktor potensial penting lainnya termasuk pajak pribadi, biaya agensi, informasi asimetris, interaksi pasar produk/input, dan pertimbangan pengendalian perusahaan. Sedangkan menurut (Aries, 2011) nilai perusahaan merupakan gambaran pencapaian sebuah perusahaan yang dilihat melalui kondisi perusahaan tersebut selama perusahaan tersebut beroperasi.

Dalam sebuah perusahaan, kemakmuran pemegang saham tercermin melalui peningkatan nilai perusahaan yang dianggap sebagai suatu prestasi oleh perusahaan tersebut. Hal tersebut dapat dilihat berdasarkan keuntungan yang didapat dari saham yang diinvestasikan oleh pemegang saham tersebut. Nilai perusahaan juga diartikan sebagai nilai pasar dari saham. Artinya, semakin tinggi nilai pasar dari saham perusahaan tersebut maka semakin tinggi nilai dari perusahaan tersebut dan sebaliknya.

Pada era persaingan global, nilai perusahaan merupakan komponen penting bagi sebuah perusahaan. Di Indonesia nilai perusahaan tersebut dapat dilihat melalui nilai saham yang tertera pada pasar modal yaitu Bursa Efek Indonesia (BEI). Berikut adalah fenomena mengenai nilai perusahaan yang dilansir dalam News Data Financial Tool Kontan, pada artikel itu disebutkan perusaahaan maskapai penerbangan yaitu PT. Garuda Indonesia Tbk. (GIAA) tengah menghadapi turbulensi.

Sejak tahun 2015 perusahaan ini terus-menerus mengalami penurunan saham dimana berdasarkan laporan tahunan tahun 2014 harga penutupan saham mencapai Rp. 555 per lembar saham. Sedangkan pada tahun 2015, harga penutupan saham GIAA hanya Rp. 309 per lembar saham. Meskipun pada tahun 2016 saham GIAA mengalami kenaikan dari tahun sebelumnya, yaitu mencapai angka Rp. 338 per lembar saham, namun pada tahun berikutnya perusahaan ini kembali mengalami penurunan harga saham dengan angka Rp. 300 per lembar saham. Penurunan sudah pasti akan mempengaruhi nilai perusahaan tersebut dimata para investor.

Dari kasus tersebut, dapat disimpukan bahwa nilai perusahaan dipengaruhi oleh beberapa faktor. Faktor-faktor yang dapat mempengaruhi nilai perusahaan yang menjadi variabel independen dalam penelitian ini adalah likuiditas, solvabilitas, dan profitabilitas.

Likuiditas merupakan salah satu pengukuran dalam kinerja perusahaan yang dilihat melalui seberapa mampu sebuah perusahaan untuk memenuhi kewajiban yang segera harus dilunasi dengan jatuh tempo maksimal satu tahun (Sitanggang, 2012). Hubungan antara likuiditas dan nilai perusahaan adalah bahwa likuiditas yang lebih tinggi dikaitkan dengan peningkatan harga saham dan pemantauan kinerja (Holmstrom dan Tirole (1993) dalam 
Batten dan Vo (2019). Penelitian yang dilakukan oleh Fadhli, Kamaliah, dan Julita (2015), Mery, Zulbahridar, dan Kurnia (2017), dan Erlina (2018) menyatakan likuiditas mempunyai pengaruh signifikan terhadap nilai perusahaan. Namun, berbeda dengan hasil penelitian yang dilakukan oleh Oktarima (2017) dan Jayanti (2018) dimana dalam hasil penelitian tersebut mereka menemukan bahwa likuiditas tidak berpengaruh terhadap nilai perusahaan.

Faktor lain yang mempengaruhi nilai perusahaan adalah solvabilitas. Solvabilitas dalam penelitian ini akan diukur oleh Debt to Equity Ratio (DER). Debt to Equity Ratio (DER) merupakan salah satu rasio solvabilitas yang digunakan untuk mendapatkan informasi umum tentang risiko keuangan dan layak atau tidaknya sebuah perusahaan dengan membandingkan jumlah hutang terhadap jumlah ekuitas. Menurut Kasmir (2012), para investor lebih memilih untuk menghindari perusahaan dengan nilai DER yang tinggi karenan para investor khawatir terhadap resiko yang akan dihadapi mengenai keuangan perusahaan tersebut. Semakin besar nilai DER, maka resiko tidak mampu membayar serta biaya bunga yang dihadapi perusahaan juga semakin besar. Apabila hal tersebut terjadi, maka dividen yang dibayarkan kepada investor menurun sebagai akibat dari kejadian tersebut dan para investor menganggap bahwa hal tersebut merupakan informasi yang buruk, sehingga permintaan terhadap saham perusahaan akan turun diikuti dengan turunnya harga saham perusahaan.

Dalam kondisi tersebut menandakan saham perusahaan kurang diminati yang secara langsung menurunkan tingkat return saham perusahaan dimana harga saham merupakan representasi dari nilai perusahaan. Penelitian yang dilakukan oleh Susilaningrum (2016) dan Erlina (2018) menghasilkan bahwa solvabilitas berpengaruh signifikan terhadap nilai perusahaan. Namun berbeda dengan penelitian yang dilakukan oleh Fadhli, Kamaliah, dan (2015) dimana dalam penelitiannya tidak menemukan adanya pengaruh solvabilitas terhadap nilai perusahaan.

Faktor yang mempengaruhi nilai perusahaan lainnya adalah profitabilitas. Besar kecilnya rasio profitabilitas yang dihasilkan oleh sebuah perusahaan dapat mempengaruhi nilai dari perusahaan tersebut dengan melihat seberapa besar laba yang dihasilkan oleh perusahaan tersebut Rudangga dan Sudiarta (2016). Menurut Sudana (2011) profitabilitas adalah rasio kinerja keuangan perusahaan yang digunakan untuk menimbang seberapa mampu perusahaan untuk memperoleh laba dengan apa yang dimiliki oleh perusahaan tersebut. Profitabilitas juga merupakan salah satu indikator penting bagi investor dalam menilai prospek perusahaan di masa depan dengan melihat sejauh mana pertumbuhan profitabilitasnya (Khumairoh, Kalbuana, dan Mulyati, 2016). Penelitian yang dilakukan oleh Indriyani (2017) dan Mery, Zulbahridar, dan Kurnia (2017) menemukan bahwa profitabilitas 
berpengaruh terhadap nilai perusahaan. Berbeda dengan penelitian yang dilakukan oleh (Putri dan Ibrahim, 2017) yang menyatakan bahwa profitabilitas tidak berpengaruh terhadap nilai perusahaan.

Ketidakkonsistenan hasil penelitian mengenai likuiditas, solvabilitas, dan profitabilitas dalam mempengaruhi nilai perusahaan mengindikasikan bahwa masih ada faktor lain yang diduga memperkuat atau memperlemah pengaruh likuiditas, solvabilitas, dan profitabilitas terhadap nilai perusahaan. Dalam hal ini kebijakan dividen diduga menjadi faktor lain yang mempengaruhi nilai perusahaan dan dalam penelitian ini, kebijakan dividen digunakan sebagai variabel pemoderasi antara likuiditas, solvabilitas dan profitabilitas terhadap nilai perusahaan.

Penelitian ini menggunakan kebijakan dividen sebagai variabel moderasi, karena keputusan kebijakan dividen adalah keputusan tentang apakah laba yang telah dihasilkan akan dibagikan kepada para pemegang saham sebagai dividen atau ditetapkan untuk laba ditahan sebagai investasi kembali bagi perusahaan (Wijaya et al., 2010). Dalam menentukan saham yang dibeli atau dijual, investor akan mempertimbangkan informasi yang tersedia. Informasi tersebut bermanfaat dalam menentukan tingkat keuntungan dan resiko saham yang akan dijual atau dibeli. Salah satu informasi tersebut adalah pengumuman pembayaran dividen. Pembagian dividen berdampak pada pendanaan perusahaan, karena perusahaan mengeluarkan kas yang besar kepada para pemegang saham. Pembagian saham secara tunai kepada pemegang saham menyebabkan posisi kas perusaahan semakin berkurang. Semakin besar pembayaran dividen maka keseluruhan posisi modal akan menurun hal tersebut menimbulkan persepsi negatif investor terhadap perusahaan sehingga menyebabkan harga saham perusahaan pada saat pembagian dividen mengalami penurunan (Kholisoh dan Agung, 2011).

Berdasarkan uraian penjelasan tersebut, terdapat kesenjangan dari penelitianpenelitian sebelumnya yang menunjukkan keanekaragaman hasil penelitian tentang faktorfaktor yang mempengaruhi nilai perusahaan. Perbedaan hasil penelitian tersebut karena adanya perbedaan pada penggunaan variabel independen dalam penelitian. Penelitian ini merupakan replikasi dari penelitian yang dilakukan oleh Rochmah dan Fitria (2017). Namun, terdapat beberapa perbedaan diantaranya: 1) Penggunaan sampel yang berbeda, dimana penelitian terdahulu hanya menggunakan sampel perusahaan sektor real estate dan property yang terdaftar di BEI Tahun 2011-2014. Sedangkan penelitian ini menggunakan sampel seluruh perusahaan yang berada di BEI Tahun 2015-2017 sehingga sampel yang digunakan diyakini lebih mewakili data yang diteliti. 2) penggunaan rumus dalam mengukur rasio 
likuiditas, dimana penelitian ini mengikuti saran dari penelitian yang dilakukan oleh Rochmah dan Fitria (2017) untuk tidak menggunakan rasio yang sama.

Dengan demikian, tujuan penelitian ini adalah: 1) Untuk menguji secara empiris pengaruh secara parsial pengaruh likuiditas, solvabilitas, dan profitabilitas terhadap nilai perusahaan. 2) Untuk menguji secara empiris pengaruh likuiditas terhadap nilai perusahaan dengan kebijakan dividen sebagai variabel moderating 3) Untuk menguji secara empiris pengaruh solvabilitas terhadap nilai perusahaan dengan kebijakan dividen sebagai variabel moderating. 4) Untuk menguji secara empiris pengaruh profitabilitas terhadap nilai perusahaan dengan kebijakan dividen sebagai variabel moderating.

\section{PENGEMBANGAN HIPOTESIS}

\section{Pengaruh Likuiditas Terhadap Nilai Perusahaan}

Likuiditas merupakan ukuran kinerja perusahaan dalam kemampuan perusahaan untuk memenuhi kewajiban keuangan yang segera harus dilunasi yaitu kewajiban keuangan yang jatuh temponya sampai dengan satu tahun (Sitanggang, 2012). Tingkat likuiditas yang tinggi menunjukkan bahwa perusahaan dalam kondisi baik, sehingga permintaan saham akan meningkat, yang mengakibatkan naiknya nilai perusahaan. Jika investor berpikir perusahaan terlalu likuid, maka harga saham akan turun. Ini berarti bahwa aset yang tidak digunakan oleh perusahaan berkurang.

Penelitian mengenai pengaruh likuiditas terhadap nilai perusahaan telah dilakukan oleh Fadhli, Kamalia, dan Julita (2015), Mery, Zulbahridar, dan Kurnia (2017), dan Erlina (2018) yang dalam hasil penelitiannya menyatakan likuiditas mempunyai pengaruh signifikan terhadap nilai perusahaan. Berdasarkan penjelasan dan hasil penelitian terdahulu mengenai pengaruh likuiditas terhadap nilai perusahaan di atas, maka hipotesis yang diajukan dalam penelitian ini adalah:

\section{$\mathrm{H}_{1}$ : Likuiditas berpengaruh terhadap nilai perusahaan.}

\section{Pengaruh Solvabilitas Terhadap Nilai Perusahaan}

Solvabilitas perusahaan merupakan mampu atau tidaknya suatu perusahaan untuk membayar atau memenuhi kewajibannya baik jangka pendek atau jangka panjang (Pasaribu, 2015). Dalam penelitian ini, rasio solvabilitas yang digunakan adalah debt to equity ratio (DER). Perusahaan dengan nilai DER yang tinggi cenderung dihindari oleh investor karena nilai DER yang tinggi mencerminkan risiko perusahaan yang relative tinggi karena semakin tinggi nilai DER, semakin besar risiko gagal bayar perusahaan. Jika ini terjadi, itu dapat 
menyebabkan pembayaran dividen yang lebih rendah karena dianggap informasi yang buruk oleh investor, sehingga pada akhirnya mempengaruhi harga saham dipasar di mana harga saham mewakili nilai perusahaan (Kasmir, 2012).

Penelitian mengenai pengaruh solvabilitas terhadap nilai perusahaan telah dilakukan oleh Susilaningrum (2016) dan Erlina (2018) yang dalam hasil penelitiannya menyatakan solvabilitas mempunyai pengaruh signifikan terhadap nilai perusahaan. Berdasarkan penjelasan dan hasil penelitian terdahulu mengenai pengaruh solvabilitas terhadap nilai perusahaan di atas, maka hipotesis yang diajukan dalam penelitian ini adalah:

\section{$\mathrm{H}_{2}$ : Solvabilitas berpengaruh terhadap nilai perusahaan.}

\section{Pengaruh Profitabilitas Terhadap Nilai Perusahaan}

Profitabilitas juga merupakan salah satu indikator penting bagi investor dalam menilai prospek perusahaan di masa depan dengan melihat sejauh mana pertumbuhan profitabilitasnya (Khumairoh, Kalbuana, dan Mulyati, 2016). Dalam penelitian ini, rasio profitabilitas yang digunakan adalah Return on Equity (ROE). Rasio ini membandingkan laba bersih bila diukur terhadap modal pemilik. Menurut Harahap (2008), semakin besar rasio ini maka lebih bagus karena dianggap perusahaan efektif dalam menggunakan ekuitasnya dalam menghasilkan laba. Return on Equity menunjukkan tingkat pengembalian yang diperoleh pemilik atau pemegang saham atas investasinya di perusahaan, dimana semakin tinggi nilai Return on Equity maka semakin baik kondisi perusahaan, semakin besar pula penghasilan yang diperoleh perusahaan dan akan meningkatkan harga saham perusahaan yang bersangkutan.

Penelitian mengenai pengaruh profitabilitas terhadap nilai perusahaan telah dilakukan oleh Indriyani (2017) dan Mery, Zulbahridar, dan Kurnia (2017) yang menemukan bahwa profitabilitas berpengaruh terhadap nilai perusahaan. Berdasarkan penjelasan dan hasil penelitian terdahulu mengenai pengaruh profitabilitas terhadap nilai perusahaan di atas, maka hipotesis yang diajukan dalam penelitian ini adalah:

\section{$\mathrm{H}_{3}$ : Profitabilitas berpengaruh terhadap nilai perusahaan.}

\section{Pengaruh Likuiditas Terhadap Nilai Perusahaan dengan Kebijakan Dividen sebagai Pemoderasi}

Kebijakan dividen merupakan keputusan keuangan perusahaan apakah laba yang diperoleh akan dibagikan kepada pemegang saham atau ditahan sebagai laba ditahan (Putra dan Lestari, 2016). Dalam penelitian ini, rasio yang digunakan untuk mengukur kebijakan 
dividen adalah Dividend Payout Ratio (DPR). Rasio ini merupakan rasio yang membandingkan antara dividen dengan laba yang tersedia bagi para pemegang saham biasa. Semakin tinggi rasio tersebut akan memberikan keuntungan bagi para investor namun dari pihak perusahaan akan memperlemah internal financing karena akan memperkecil laba ditahan. Tetapi sebaliknya DPR semakin kecil akan merugikan para pemegang saham (investor) tetapi internal financing perusahaan semakin kuat (Husnan 2001 dalam Indayani dan Yahya, 2013).

Penelitian mengenai pengaruh kebijakan dividen sebagai pemoderasi antara likuiditas terhadap nilai perusahaan telah diteliti oleh (Fadhli, Kamaliah, dan Julita, 2015) yang menyatakan likuiditas yang dinilai dari arus kas bebas perusahaan memiliki pengaruh terhadap nilai perusahaan. Berdasarkan penjelasan dan hasil penelitian terdahulu mengenai pengaruh kebijakan dividen sebagai pemoderasi antara likuiditas terhadap nilai perusahaan di atas, maka hipotesis yang diajukan dalam penelitian ini adalah:

\section{H4: Kebijakan dividen mampu memoderasi pengaruh likuiditas terhadap nilai perusahaan.}

\section{Pengaruh Solvabilitas Terhadap Nilai Perusahaan dengan Kebijakan Dividen sebagai Pemoderasi}

Kemampuan membayar dividen begitu erat hubungannya dengan kemampuan perusahaan memperoleh laba. Jika perusahaan memperoleh laba yang besar, maka kemampuan perusahaan membayar dividen juga besar. Pada dasarnya, laba tersebut bisa dibagi sebagai dividen atau ditahan untuk diinvestasikan kembali (Rochmah dan Fitria, 2017).

Dalam penelitian yang dilakukan oleh Rochmah dan Fitria (2017), mengungkapkan bahwa kebijakan dividen mampu secara signifikan memoderasi pengaruh leverage terhadap nilai perusahaan yang mana leverage merupakan kata lain dari solvabilitas. Berdasarkan penjelasan dan hasil penelitian terdahulu mengenai pengaruh kebijakan dividen sebagai pemoderasi antara solvabilitas terhadap nilai perusahaan di atas, maka hipotesis yang diajukan dalam penelitian ini adalah:

\section{H5: Kebijakan dividen mampu memoderasi pengaruh solvabilitas terhadap nilai perusahaan.}

\section{Pengaruh Profitabilitas Terhadap Nilai Perusahaan dengan Kebijakan Dividen sebagai Pemoderasi}

Jika perusahaan mampu meningkatkan pembayaran dividen karena peningkatan laba, 
maka harga saham akan naik yang mana harga saham merupakan representasi dari nilai perusahaan (Rochmah dan Fitria, 2017). Menurut Mery, Zulbahridar, dan Kurnia (2017) mengungkapkan bahwa kebijakan dividen mampu memoderasi pengaruh profitabilitas terhadap nilai perusahaan yang mengartikan bahwa kebijakan dividen mampu meningkatkan nilai perusahaan pada saat profitabilitas tinggi dan kebijakan dividen mampu menurunkan nilai perusahaan pada saat profitabilitas rendah.

Berdasarkan penjelasan dan hasil penelitian terdahulu mengenai pengaruh kebijakan dividen sebagai pemoderasi antara profitabilitas terhadap nilai perusahaan di atas, maka hipotesis yang diajukan dalam penelitian ini adalah:

\section{H6: Kebijakan dividen mampu memoderasi pengaruh profitabilitas terhadap nilai perusahaan.}

Berdasarkan tujuan penelitian, tinjauan pustaka, dan hasil penelitian terdahulu serta permasalahan yang telah dikemukakan maka sebagai dasar merumuskan hipotesis, disajikan kerangka pemikiran yang dapat dilihat pada Gambar 1:

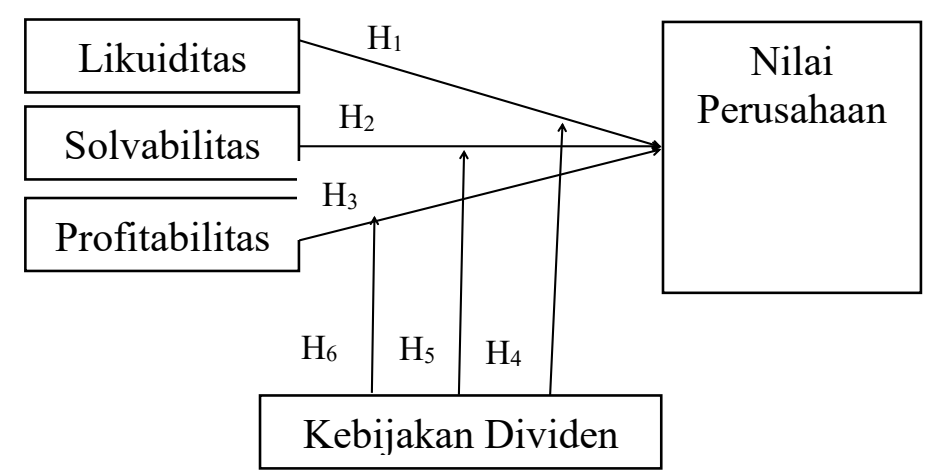

Gambar 1

Kerangka Konseptual

Sumber: Data Olahan, 2019

\section{METODE PENELITIAN}

\section{Populasi dan Sampel Penelitian}

Populasi dalam penelitian ini adalah seluruh perusahaan yang terdaftar di Bursa Efek Indonesia pada tahun 2015 sampai 2017. Sedangkan sampel dalam penelitian ini diambil menggunakan teknik purposive sampling karena penelitian ini memiliki kriteria sampel tertentu, yaitu: 1) Seluruh perusahaan yang sudah terdaftar (kecuali bank dan lembaga keuangan lainnya) di Bursa Efek Indonesia sejak periode penelitian (2015-2017). 2) Perusahaan yang membagikan dividen secata kontinyu selama periode penelitian. 3) Perusahaan yang dalam laporan keuangannya tidak memiliki saldo total ekuitas negative dan 
atau mengalami kerugian selama tahun penelitian. 4) Perusahaan yang menggunakan mata uang rupiah. Berdasarkan kriteria tersebut, jumlah perusahaan yang dijadikan sampel adalah sebanyak 108 perusahaan dari total populasi dengan 3 periode penelitian.

Teknik pengumpulan data yang digunakan dalam penelitian ini adalah dengan menggunakan teknik dokumentasi yaitu dengan mencari dan mengumpulkan data mengenai hal-hal yang berupa catatan, transkrip, buku, surat kabar dan media lainnya (Arikunto, 2013:274). Data yang digunakan dalam penelitian ini seluruhnya adalah data sekunder yang berbentuk laporan keuangan dan laporan tahunan perusahaan yang diperoleh dari Bursa Efek Indonesia, Indonesia Capital Market Directory (ICMD), media internet dan web-site lainnya dengan menggunakan teknik pengumpulan data dokumentasi yaitu dengan mencari dan mengumpulkan data mengenai hal-hal yang bersangkutan dengan penelitian.

\section{Definisi Operasional dan Pengukuran Variabel}

Dalam penelitian ini, peneliti menggunakan lima variabel yaitu variabel dependen (nilai perusahaan), variabel independen (likuiditas, solvabilitas, dan profitabilitas), dan variabel moderasi (kebijakan dividen) dengan menggunakan skala rasio yang disajikan pada Tabel berikut:

Tabel 1

Matrik Definisi Operasional Variabel

\begin{tabular}{|c|c|c|c|}
\hline Variabel & 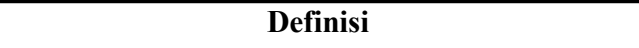 & Rumus & Ukuran \\
\hline $\begin{array}{l}\text { Nilai perusahaan } \\
\text { (Y) }\end{array}$ & $\begin{array}{l}\text { Nilai perusahaan merupakan kondisi yang } \\
\text { menggambarkan pencapaian suatu perusahaan } \\
\text { selama proses beroperasinya yang } \\
\text { dipresentasikan dengan nilai saham (Aries, } \\
\text { 2011). }\end{array}$ & $\begin{array}{l}\text { Tobin's Q }= \\
\text { (Prasetyorini, 2013) }\end{array}$ & Rasio \\
\hline Likuiditas (X1) & $\begin{array}{l}\text { Likuiditas kemampuan perusahaan dalam } \\
\text { memenuhi kewajiban jangka pendeknya yang } \\
\text { segera jatuh tempo dengan menggunakan aset } \\
\text { lancar yang tersedia (Fahmi, 2014) }\end{array}$ & $\begin{array}{l}\text { Rasio Cepat }= \\
\quad \frac{\text { Aset Lancar-Per }}{\text { Utang Lanc }} \\
\text { (Hery, 2016) }\end{array}$ & Rasio \\
\hline Solvabilitas (X2) & $\begin{array}{l}\text { Solvabilitas merupakan rasio yang mengukur } \\
\text { seberapa jauh perusahaan dibiayai oleh } \\
\text { kewajiban atau pihak luar dengan kemampuan } \\
\text { perusahaan yang digambarkan oleh ekuitas } \\
\text { (Harahap, 2008). }\end{array}$ & $\begin{array}{l}\quad \text { DER }= \\
\text { (Rochmah dan Fitria, 2017) }\end{array}$ & Rasio \\
\hline $\begin{array}{l}\text { Profitabilitas } \\
\text { (X3) }\end{array}$ & $\begin{array}{l}\text { Profitabilitas adalah rasio untuk mengukur } \\
\text { kemampuan perusahaan untuk menghasilkan } \\
\text { laba dengan menggunakan sumber-sumbernya } \\
\text { yang dimiliki perusahaan, seperti aktiva, modal, } \\
\text { atau penjualan perusahaan (Sudana, 2011). }\end{array}$ & Return On Equity $($ ROE $)=$ & Rasio \\
\hline $\begin{array}{l}\text { Kebijakan } \\
\text { Dividen (Z) }\end{array}$ & $\begin{array}{l}\text { Kebijakan dividen merupakan keputusan } \\
\text { keuangan perusahaan apakah laba yang } \\
\text { diperoleh akan dibagikan kepada pemegang } \\
\text { saham atau ditahan sebagai laba ditahan (Putra } \\
\text { dan Lestari, 2016). }\end{array}$ & $\begin{array}{l}\mathrm{DPR}=\frac{\text { Di videnpersaham }}{\text { Lababersihpersaham }} \\
\text { (Rochmah dan Fitria, 2017) }\end{array}$ & Rasio \\
\hline
\end{tabular}

Sumber: Olah data dengan menggunakan SPSS 


\section{Teknik Analisis Data}

Pada penelitian ini dilakukan uji normalitas data dengan teknik Kolmogorov - Smirnov. Sebuah data dikatakan normal apabila tingkat signifikan Kolmogorov Smirnov hitungnya lebih besar dari sig penelitian (Sig Kolmogorov Smirnov > 0,05). Sebelum melakukan uji hipotesis, terlebih dahulu dilakukan uji asumsi klasik. Uji asumsi klasik dilakukan untuk menentukan kecocokan antara jenis sampel dengan metode untuk menguji hipotesis. Uji asumsi klasik terdiri dari tiga uji yaitu: uji multikolonieritas, uji heteroskedastisitas, dan uji autokorelasi (Ghozali, 2013).

Setelah melakukan uji asumsi klasik, maka akan ditentukan model regresi yang akan digunakan dengan menggunakan analisis regresi linear berganda (multiple regression analysis dan moderate regression analysis (MRA) dengan bantuan software SPSS serta melakukan uji hipotesis yaitu uji $\mathrm{t}$, dan uji determinasi.

Persamaan dibawah ini digunakan untuk menguji hipotesis dalam penelitian ini:

$$
\begin{aligned}
& Y=\alpha+\beta_{1} X_{1}+\beta_{2} X_{2}+\beta_{3} X_{3}+\varepsilon \\
& Y=\alpha+\beta_{1} X_{1}+\beta_{2} Z+\beta_{3} X_{1} \cdot Z+\varepsilon \\
& Y=\alpha+\beta_{1} X_{2}+\beta_{2} Z+\beta_{3} X_{2} \cdot Z+\varepsilon \\
& Y=\alpha+\beta_{1} X_{3}+\beta_{2} Z+\beta_{3} X_{3} \cdot Z+\varepsilon
\end{aligned}
$$

Keterangan:

$\mathrm{Y} \quad=$ nilai perusahaan

$\alpha \quad=$ konstanta

$\beta 1 \beta 2 \beta 3=$ koefisien regresi

$\mathrm{X}_{1} \quad=$ likuiditas

$\mathrm{X}_{2}=$ solvabilitas

$\mathrm{X}_{3} \quad=$ profitabilitas

$\mathrm{Z} \quad=$ kebijakan dividen

$\varepsilon \quad=$ eror

\section{HASIL PENELITIAN DAN PEMBAHASAN}

\section{Hasil Uji Statistik Deskriptif}

Menurut Sugiyono (2014) statistik deskriptif adalah statistik untuk menganalisa data dengan cara mendeskripsikan atau menggambarkan data yang telah terkumpul sebagaimana adanya tanpa bermaksud membuat kesimpulan yang berlaku untuk umum atau generalisasi. Statistik deskriptif yang digunakan pada penelitian ini meliputi nilai minimum, maksimum, mean, dan standar deviasi dari satu variabel dependen yaitu nilai perusahaan, tiga variabel 
independen yaitu likuiditas, solvabilitas, profitabilitas, dan satu variabel moderasi yaitu kebijakan dividen. Hasil statistik deskriptif disajikan pada Tabel 2.

Tabel 2

Hasil Uji Statistik Deskriptif

\begin{tabular}{lccccc}
\hline & N & Minimum & Maximum & Mean & Std. Deviation \\
\hline Nilai Perusahaan & 324 & 0,09 & 23,29 & 2,7151 & 2,30227 \\
Likuiditas & 324 & 0,01 & 7,84 & 1,5839 & 1,28324 \\
Solvabilitas & 324 & 0,08 & 6,87 & 1,0457 & 0,91031 \\
Profitabilitas & 324 & 0,00 & 1,61 & 0,1566 & 0,19411 \\
DPR & 324 & 0,00 & 23,92 & 1,5033 & 1,42132 \\
Valid N (listwise) & 324 & & & & \\
\hline
\end{tabular}

Sumber: Olah data dengan menggunakan SPSS

Dari Tabel 2 diketahui bahwa nilai mean nilai perusahaan sebesar 2,7151 lebih besar dari standar deviasinya sebesar 2,30227 hal ini menunjukkan hasil yang normal dan tidak menyebabkan bias dan itu berarti data mengenai nilai perusahaan mengalami fluktuasi yang cukup besar. Begitu juga dengan data mengenai likuiditas, solvabilitas dan kebijakan dividen yang mana tabel di atas menunjukkan bahwa masing-masing nilai mean variabel tersebut lebih besar dari standar deviasinya. Berbeda dengan data mengenai profitabilitas dimana nilai mean sebesar 0,1566 lebih kecil dari standar deviasi 0,19411 dan dengan hasil data tersebut menunjukkan bahwa data mengenai profitabilitas tidak mengalami fluktuasi yang cukup besar.

\section{Hasil Uji Normalitas Data}

Berikut hasil uji normalitas dengan kolmogrov smirnov setelah transformasi menggunakan logaritma natural:

Tabel 3

Hasil Uji Normalitas

\begin{tabular}{lll}
\hline & & Unstandardized Residual \\
\hline $\mathrm{N}$ & & 324 \\
Normal Parameters & Mean & .0000000 \\
& Std. Deviation & 0,55437004 \\
Most Extreme Differences & Absolute & 0,047 \\
& Positive & 0,047 \\
Test Statistic & Negative & $-0,038$ \\
Asymp. Sig. (2-tailed) & & 0,047 \\
a. Test distribution is Normal. & & $0,079^{\mathrm{c}}$ \\
b. Calculated from data. & \\
c. Lilliefors Significance Correction. & \\
\hline Sumber: Olahdata dengan
\end{tabular}

Sumber: Olah data dengan menggunakan SPSS

Berdasarkan Tabel 3 di atas dapat disimpulkan bahwa data sudah terdistribusi secara normal yang ditunjukkan dengan nilai signifikansi Asyimp. Sig (2-tailed) N 324 lebih besar dari 0,05 atau $0,079>0,05$. 


\section{Hasil Uji Asumsi Klasik}

Uji asumsi klasik dilakukan untuk menentukan kecocokan antara jenis sampel dengan metode untuk menguji hipotesis. Uji asumsi klasik terdiri dari uji multikolinearitas, uji heteroskedastisitas, dan uji autokorelasi (Ghozali, 2013).

\section{Hasil Uji Multikolinearitas}

Uji multikolinearitas merupakan pengujian yang bertujuan untuk menguji apakah dalam sebuah model regresi ditemukan adanya korelasi antar variabelnya (Ghozali, 2013). Hasil uji multikolinearitas disajikan pada Tabel 4.

Tabel 4

Hasil Uji Multikolinearitas

\begin{tabular}{|c|c|c|c|c|c|c|c|c|}
\hline \multirow{2}{*}{\multicolumn{2}{|c|}{ Model }} & \multicolumn{2}{|c|}{$\begin{array}{c}\text { Unstandardized } \\
\text { Coefficients }\end{array}$} & \multirow{2}{*}{$\begin{array}{c}\begin{array}{c}\text { Standardized } \\
\text { Coefficients }\end{array} \\
\text { Beta } \\
\end{array}$} & \multirow[t]{2}{*}{$\mathbf{T}$} & \multirow[t]{2}{*}{ Sig. } & \multicolumn{2}{|c|}{$\begin{array}{c}\text { Collinearity } \\
\text { Statistics }\end{array}$} \\
\hline & & B & Std. Error & & & & Tolerance & VIF \\
\hline \multirow{4}{*}{1} & (Constant) & 1,571 & 0,092 & & 17,026 & 0,000 & & \\
\hline & Ln_Likuiditas & 0,082 & 0,052 & 0,082 & 1,579 & 0,115 & 0,715 & 1,399 \\
\hline & Ln_Solvabilitas & $-0,177$ & 0,046 & $-0,203$ & $-3,884$ & 0,000 & 0,708 & 1,412 \\
\hline & Ln_Profitabilitas & 0,524 & 0,039 & 0,591 & 13,380 & 0,000 & 0,988 & 1,012 \\
\hline
\end{tabular}

Sumber: Olah data menggunakan SPPS

Berdasarkan Tabel 4 di atas, dapat dilihat nilai tolerance masing-masing variabel independen lebih dari 0,1 dimana variabel likuiditas memiliki nilai tolerance sebesar 0,715, variabel solvabilitas sebesar 0,708 dan variabel profitabilitas sebesar 0,988. Tabel di atas juga menunjukkan bahwa tidak ada variabel yang memiliki nilai VIF lebih dari 10. Dengan demikian dapat disimpulkan model regresi tersebut tidak multikolinearitas maka model regresi yang ada layak untuk dipakai.

\section{Hasil Uji Heteroskedastisitas}

Pengujian heteroskedastisitas bertujuan untuk menguji apakah terjadi ketidaksamaan varians dari residual satu pengamatan ke pengamatan yang lain. Model regresi yang baik adalah yang tidak terjadi heteroskedastisitas dengan melihat pola gambar scatterplot model tersebut (Ghozali, 2013). Hasil uji heteroskedastisitas disajikan pada Gambar 2.

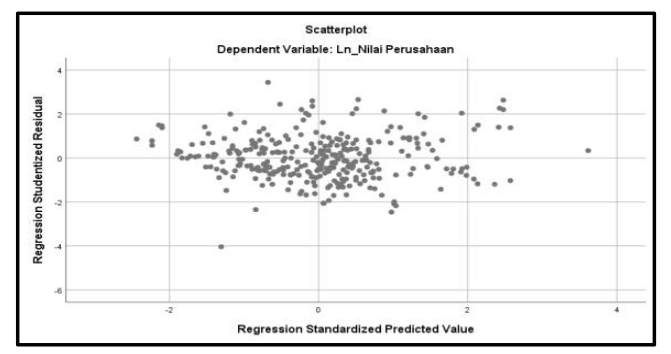

\section{Gambar 2}

Hasil Uji Heteroskedastisitas

Sumber: Olah data menggunakan SPSS 
Berdasarkan Gambar 2, dapat dilihat bahwa titik-titik yang ada tidak membentuk pola tertentu yang teratur, tetapi tidak ada pola yang jelas, serta titik-titik menyebar di atas dan di bawah angka 0 pada sumbu Y. berdasarkan penjelasan tersebut, maka dapat disimpulkan tidak terjadi heteroskedastisitas.

\section{Hasil Uji Autokorelasi}

Uji autokorelasi adalah uji yang dilakukan uuntuk melihat apakah terjadi korelasi antara satu periode $t$ dengan periode sebelumnya (t-1) yang hanya dilakukan pada data time series (Sunjoyo et al., 2013). Salah satu cara untuk mendeteksi ada atau tidaknya autokorelasi yaitu dengan uji Durbin-Watson yang digunakan untuk autokorelasi tingkat satu dan mensyaratkan adanya konstanta dalam model regresi dan tidak ada variabel lag diantara variabel independen (Ghozali, 2013). Hasil uji autokorelasi disajikan pada Tabel 5.

\section{Tabel 5}

Hasil Uji Autokorelasi

\begin{tabular}{cccccc}
\hline Model & R & R Square & $\begin{array}{c}\text { Adjusted R } \\
\text { Square }\end{array}$ & $\begin{array}{c}\text { Std. Error of } \\
\text { the Estimate }\end{array}$ & Durbin-Watson \\
\hline 1 & $0,624^{\mathrm{a}}$ & 0,389 & 0,383 & 0,58404 & 2,001
\end{tabular}

a. Predictors: (Constant), Ln_Profitabilitas, Ln_Likuiditas, Ln_Solvabilitas

b. Dependent Variable: Ln_Nilai Perusahaan

Sumber: Olah data menggunakan SPSS

Berdasarkan Tabel 5 dapat diketahui bahwa nilai Durbin-Watson pada nilai perusahaan sebesar 2,001, selanjutnya nilai ini dibandingkan dengan nilai signifikansi 5\%. Jumlah sampel $\mathrm{N}=324$ sampel dan jumlah variabel independen sebanyak $3(\mathrm{~K}=3)$, maka pada tabel Durbin-Watson diperoleh nilai du sebesar 1,80804. Karena nilai DW lebih besar dari batas atas (du) dan lebih kecil dari 4-du $(2,19196)$ maka dapat dapat disimpulkan tidak terdapat autokorelasi positif maupun negatif pada pengujian ini.

\section{Hasil Uji Koefisien Determinasi $\left(R^{2}\right)$}

Imam Ghozali (2013) menyatakan bahwa koefisien determinasi mengukur seberapa jauh kemampuan model dalam menerangkan variasi variabel dependen yang bertujuan untuk mengetahui persentasi besarnya pengaruh variabel bebas terhadap variabel terikat. Hasil uji koefisien determinasi $\left(\mathrm{R}^{2}\right)$ disajikan pada Tabel 6.

Tabel 6

Hasil Uji Koefisien Determinasi

\begin{tabular}{llccc}
\hline Model & R & R Square & Adjusted R Square & Std. Error of the Estimate \\
\hline 1 & $0.624^{\mathrm{a}}$ & 0.389 & 0.383 & 0.58404 \\
\hline
\end{tabular}

Sumber: Olah data menggunakan SPSS 
Berdasarkan Tabel 6, nilai koefisien determinasi $\left(\mathrm{R}^{2}\right)$ diperoleh angka sebesar 0,389 yang artinya korelasi ganda antara variabel dependen memiliki hubungan yang cukup kuat. Hal ini menunjukkan bahwa 38,9\% variasi variabel nilai perusahaan dapat dijelaskan oleh variabel likuiditas, solvabilitas, dan profitabilitas. Sedangkan $61,1 \%$ lainnya dijelaskan oleh faktor-faktor lain diluar model yang diteliti.

\section{Hasil Pengujian Hipotesis}

Hasil analisis regresi linear berganda dan Moderate Regression Analysis (MRA) disajikan pada Tabel 7 dan 8 .

\section{Tabel 7}

Hasil Uji t Analisis Regresi Linier Berganda

\begin{tabular}{|c|c|c|c|c|c|}
\hline \multirow[b]{2}{*}{ Model } & \multicolumn{2}{|c|}{$\begin{array}{l}\text { Unstandardized } \\
\text { Coefficients }\end{array}$} & \multirow{2}{*}{$\begin{array}{c}\text { Standardized Coefficients } \\
\text { Beta }\end{array}$} & \multirow[b]{2}{*}{$\mathbf{T}$} & \multirow[b]{2}{*}{ Sig. } \\
\hline & B & Std. Error & & & \\
\hline 1 (Constant) & 1,571 & 0,092 & & 17,026 & 0,000 \\
\hline Ln_Likuiditas & 0,082 & 0,052 & 0,082 & 1,579 & 0,115 \\
\hline Ln Solvabilitas & $-0,177$ & 0,046 & $-0,203$ & $-3,884$ & 0,000 \\
\hline Ln Profitabilitas & 0,524 & 0,039 & 0,591 & 13,380 & 0,000 \\
\hline
\end{tabular}

a. Dependent Variable: Ln Nilai Perusahaan

\section{Sumber: Olah data menggunakan SPSS}

Tabel 8

Hasil Uji t MRA

\begin{tabular}{lccccc}
\hline & \multicolumn{2}{c}{$\begin{array}{c}\text { Unstandardized } \\
\text { Coefficients }\end{array}$} & Standardized Coefficients & & \\
\cline { 2 - 4 } Model & B & Std. Error & Beta & T & Sig. \\
\hline Moderating 1 & $-0,046$ & 0,057 & $-0,064$ & $-0,794$ & 0,428 \\
Moderating 2 & 0,218 & 0,050 & 0,345 & 4,321 & 0,000 \\
Moderating 3 & 0,064 & 0,024 & 0,178 & 2,707 & 0,007 \\
\hline
\end{tabular}

Sumber: Olah data menggunakan SPSS

\section{PEMBAHASAN}

\section{Pengaruh Likuiditas Terhadap Nilai Perusahaan}

Hasil penelitian ini menunjukkan bahwa variabel likuiditas memiliki t-hitung sebesar 1,579 dan $\mathrm{t}_{\text {-tabel }}$ sebesar 1,967 menunjukkan bahwa $\mathrm{t}$-hitung $<\mathrm{t}$-tabel $(1,579<1,967)$ dan nilai signifikansi sebesar 0,115 yang artinya lebih besar dari tingkat signifikansi $0,05(0,115>$ 0,05). Berdasarkan penjelasan tersebut, dapat disimpulkan bahwa likuiditas tidak berpengaruh terhadap nilai perusahaan, sehingga hipotesis pertama $\left(\mathrm{H}_{1}\right)$ ditolak. Hasil tersebut menunjukkan bahwa likuiditas tidak memiliki pengaruh yang signifikan terhadap nilai perusahaan pada perusahaan yang terdaftar di BEI.

Rasio cepat (quick ratio) yang digunakan dalam penelitian ini lebih menggambarkan kemampuan perusahaan dalam memenuhi kebutuuhan modal kerja dalam waktu yang lebih 
cepat. Hal ini terjadi karena menurut Brigham dan Houston (2001) dalam Rochmah dan Fitria (2017) likuiditas didefinisikan sebagai ketidakpastian yang melekat dalam proyeksi tingkat pengembalian asset masa depan, yang mana hal tersebut merupakan satu-satunya determinan terpenting dari nilai perusahaan. Hal ini sesuai dengan teori pecking order yang menyatakan meskipun perusahaan dianggap tidak atau terlalu likuid yang artinya terdapat aktiva produktif yang tidak dimanfaatkan oleh perusahaan karena memiliki dana internal yang lebih besar, sehingga perusahaan tersebut akan menggunakan dana internalnya terlebih dahulu. Maka dari itu, tinggi atau rendahnya tingkat likuiditas pada suatu perusahaan tidak mempengaruhi minat beli investor terhadap saham perusahaan tersebut yang mana nilai saham merupakan representasi dari nilai perusahaan.

\section{Pengaruh Solvabilitas Terhadap Nilai Perusahaan}

Hasil penelitian ini menunjukkan bahwa variabel solvabilitas memiliki t-hitung sebesar 3,884 dan $t_{\text {-tabel }}$ sebesar 1,967 menunjukkan bahwa $t_{\text {-hitung }}>\mathrm{t}$-tabel $(-3,884>1,967)$ dan nilai signifikansi sebesar 0,000 yang artinya lebih kecil dari tingkat signifikansi $0,05(0,000<0,05)$. Berdasarkan penjelasan tersebut, dapat disimpulkan bahwa solvabilitas berpengaruh negatif dan signifikan terhadap nilai perusahaan, sehingga hipotesis kedua $\left(\mathrm{H}_{2}\right)$ diterima. Solvabilitas memiliki pengaruh negative terhadap nilai perusahaan yang artinya semakin tinggi nilai DER suatu perusahaan, maka semakin rendah nilai perusahaan dari perusahaan tersebut. Menurut Kasmir (2012) apabila DER semakin tinggi, sementara proporsi total aktiva dan atau total hutang tidak berubah maka hutang yang dimilika perusahaan semakin besar. Total hutang yang semakin besar berarti risiko financial atau kegagalan perusahaan untuk mengembalikan pinjaman semakin tinggi. Maka dari itu, investor cenderung menghindari sham-saham yang memiliki nilai DER yang tinggi. Itu sebabnya dalam teori pecking order dijelaskan mengapa perusahaan yang profitable umumnya meminjam dalam jumlah sedikit. Hal tersebut bukan karena mereka mempunyai target debt ratio yang rendah, tetapi mereka memerlukan external financing yang sedikit untuk menjaga pandangan investor terhadap perusahaan yang berpengaruh kepada nilai perusahaan.

\section{Pengaruh Profitabilitas Terhadap Nilai Perusahaan}

Hasil pengujian menunjukkan bahwa variabel profitabilitas memiliki t-hitung sebesar 13.380 dan $t$-tabel sebesar 1,967 menunjukkan bahwa $t$-hitung $>t$-tabel $(13.380>1,967)$ dan nilai signifikansi sebesar 0,000 yang artinya lebih kecil dari tingkat signifikansi $0,05(0,000<0,05)$. Berdasarkan penjelasan tersebut, dapat disimpulkan bahwa profitabilitas berpengaruh positif 
dan signifikan terhadap nilai perusahaan, sehingga hipotesis ketiga diterima. Dalam penelitian ini rasio profitabilitas yang digunakan adalah Return on Equity (ROE). Rasio ini menunjukkan tingkat pengembalian yang diperoleh pemilik atau pemegang saham atas investasinya di perusahaan, semakin tinggi nilai ROE menunjukkan semakin baiknya kondisi perusahaan. Semakin besar penghasilan yang diperoleh perusahaan akan meningkatkan harga saham perusahaan, harga saham tersebut merupakan representasi dari nilai perusahaan itu sendiri. Penjelasan tersebut sejalan dengan teori sinyal (signalling theory) yang menyatakan bahwa perusahaan dengan prospek yang menguntungkan akan berusaha meyakinkan investor dengan menunjukkan laba perusahaan yang tinggi yang berarti kemakmuran perusahaan bagus sehingga investor akan tertarik dan merespon positif hal tersebut dan permintaan akan harga saham akan meningkat yang mengakibatkan meningkatnya nilai perusahaan.

\section{Pengaruh Likuiditas Terhadap Nilai Perusahaan dengan Kebijakan Dividen Sebagai Pemoderasi}

Hasil penelitian ini menunjukkan bahwa t-hitung $<\mathrm{t}_{\text {-tabel }}(-0,794<1,967)$. Nilai signifikansi sebesar 0,428 yang artinya lebih besar dari tingkat signifikansi $0,05(0,428>$ 0,05). Hal ini menunjukkan bahwa kebijakan dividen tidak mampu memoderasi hubungan antara likuiditas terhadap nilai perusahaan. Berdasarkan penjelasan tersebut, maka hipotesis keempat $\left(\mathrm{H}_{4}\right)$ ditolak. Hasil pengujian menunjukkan bahwa kebijakan dividen tidak memoderasi pengaruh likuiditas terhadap nilai perusahaan. Kebijakan dividen tidak dapat meningkatkan nilai perusahaan pada saat likuiditas tinggi dan kebijakan dividen tidak mampu menurunkan nilai perusahaan pada saat likuiditas rendah yang artinya semakin tinggi atau rendahnya kebijakan dividen tidak mempengaruhi hubungan antara likuiditas terhadap nilai perusahaan. Kondisi ini juga menggambarkan bahwa pembayaran dividen membawa sedikitnya pengaruh negatif terhadap likuiditas perusaahaan. Karena dengan adanya pembayaran dividen tunai perusahaan mengeluarkan kas dalam jumlah yang cukup besar. Hal ini disebabkan perusahaan yang memiliki tingkat likuiditas yang tinggi cenderung memiliki dana internal yang besar, sehingga perusahaan tersebut tentu akan menggunakan dana internalnya terlebih dahulu, yang sejalan dengan teori pecking order yang dikemukakan oleh Donaldson pada tahun 1961. 
Pengaruh Solvabilitas Terhadap Nilai Perusahaan dengan Kebijakan Dividen Sebagai Pemoderasi

Hasil penelitian ini menunjukkan bahwa $t$-hitung $>\mathrm{t}$-tabel $(4,321>1,967)$. Nilai signifikansi sebesar 0,000 yang artinya lebih kecil dari tingkat signifikansi $0,05(0,000<0,05)$. Hal ini menunjukkan bahwa kebijakan dividen mampu memoderasi hubungan antara solvabilitas terhadap nilai perusahaan. Berdasarkan penjelasan tersebut, maka hipotesis kelima $\left(\mathrm{H}_{5}\right)$ diterima. Solvabilitas merupakan modal perusahaan yang berasal dari luar dan sifatnya sementara dalam perushaan sehingga ada saatnya nanti harus dikembalikan. Peran kebijakan dividen dalam memoderasi pengaruh solvabilitas terhadap nilai perusahaan adalah semakin tinggi hutang yang dimiliki, semakin kecil kemampuan perusahaan memenuhi kewajibannya kepada pemegang saham berupa dividen, maka itu akan dianggap sebagai sinyal buruk oleh para investor dan semakin buruk penilaian investor terhadap perusahaan maka akan mengakibatkan penurunan permintaan akan harga saham perusahaan tersebut dimana harga saham merupakan representasi dari nilai perusahaan.

\section{Pengaruh Profitabilitas Terhadap Nilai Perusahaan dengan Kebijakan Dividen Sebagai Pemoderasi}

Hasil penelitian ini menunjukkan bahwa $\mathrm{t}$-hitung $>\mathrm{t}$-tabel $(2,707>1,967)$. Nilai signifikansi sebesar 0,007 yang artinya lebih kecil dari tingkat signifikansi 0,05 $(0,007<0,05)$. Hal ini menunjukkan bahwa kebijakan dividen mampu memoderasi hubungan antara profitabilitas terhadap nilai perusahaan. Berdasarkan penjelasan tersebut, maka hipotesis keenam $\left(\mathrm{H}_{6}\right)$ diterima. Profitabilitas yang tinggi serta kebijakan dividen (DPR) yang optimal mencerminkan prospek perusahaan yang baik sehingga dapat menambah permintaan akan saham perusahaan tersebut yang berakibat naiknya harga saham. Berdasarkan signaling theory yang menyatakan naiknya pembayaran dividen kepada investor atau perusahaan dianggap sinyal baik, karena mengidentifikasikan kondisi dan memberikan pandangan kedepan bagaimana kondisi perusahaan di masa yang akan datang, sehingga mengakibatkan reaksi positif dari para investor. Salah satu teori preferensi investor yaitu teori bird in the hand juga menyatakan bahwa investor menyukai dividen yang tinggi. Maka dari itu jika perusahaan mampu meningkatkan pembayaran dividen karena peningkatan atau laba yang tinggi, maka harga saham akan naik (Rochmah dan Fitria, 2017). 


\section{SIMPULAN}

Berdasarkan data yang telah dikumpulkan dan pengujian yang telah dilakukan terhadap permasalahan dengan menggunakan model regresi berganda dan MRA, maka dapat diambil kesimpulan sebagai berikut: Likuiditas tidak berpengaruh terhadap nilai perusahaan. Namun solvabilitas berpengaruh negatif terhadap nilai perusahaan. Profitabilitas berpengaruh positif terhadap nilai perusahaan. Kebijakan dividen tidak mampu memoderasi pengaruh likuiditas terhadap nilai perusahaan. Kebijakan dividen mampu memoderasi pengaruh solvabilitas terhadap nilai perusahaan. Kebijakan dividen mampu memoderasi pengaruh profitabilitas terhadap nilai perusahaan.

Dalam penelitian ini masih terdapat kelemahan dan keterbatasan yang dapat diperbaiki oleh peneliti selanjutnya. Beberapa keterbatasan yang perlu diperbaiki antara lain: Tahun penelitian yang terbatas hanya tiga tahun (2015-2017) sehingga belum dapat mengetahui pengaruh variabel independen dalam jangka panjang. Variabel independen yang digunakan hanya likuiditas, solvabilitas, dan profitabilitas sehingga perlu ditambahkan variabel lain dalam melihat apa saja faktor-faktor yang mempengaruhi nilai perusahaan

Dengan segala keterbatasan di atas, maka peneliti memberikan saran untuk penelitian selanjutnya, antara lain: Penelitian selanjutnya diharapkan dapat menambah periode penelitian agar mendapatkan gambaran yang lebih komprehensif sehingga mendapatkan kesimpulan yang lebih valid. Penelitian selanjutnya diharapkan dapat menambah variabel independen lain yang diduga mempunyai pengaruh terhadap nilai perusahaan seperti, keputusan investasi, struktur modal, ukuran perusahaan, dan faktor lainnya. Penelitian selanjutnya disarankan untuk mengganti atau menambah variabel moderasi lainnya untuk melihat pengaruhnya terhadap nilai perusahaan.

\section{REFERENSI}

Aries, H. P. (2011). Valuasi Perusahaan. Jakarta: PPM.

Arikunto, S. (2013). Metodologi Penelitian. Yogyakarta: Bina Aksara.

Batten, J., \& Vo, X. V. (2019), Liquidity and Firm Value in an Emerging Market. The Singapore Economic Review, 64(02), 365-379. https://doi.org/10.1142/ S0217590817470063

Brigham, E. F., \& Houston, J. F. (2011), Dasar-Dasar Manajemen Keuangan Buku 2, edisi 11, Jakarta: Salemba Empat.

Chowdhury, A., \& Chowdhury, S. P. (2010). Impact Of Capital Structure On Firm 's Value : 
Evidence From Bangladesh. Business and Economic Horizons, 3(3), 111-122.

Erlina, N. (2018). Pengaruh Likuiditas, Solvabilitas, Profitabilitas Terhadap Nilai Perusahaan Pertambangan Di Bursa Efek Indonesia. Jurnal Manajemen Kompeten, 1(1), 13-28.

Fadhli, M., Kamaliah., \& Julita. (2015). Pengaruh Likuiditas, Solvabilitas dan Profitabilitas terhadap Nilai Perusahaan dengan Kebijakan Dividen sebagai Variabel Moderasi pada Perusahaan Perbankan, Asuransi \& Lembaga Keuangan Lainnya di Bursa Efek Indonesia Tahun 2010-2013. Jurnal Online Mahasiswa Fakultas Ekonomi Universitas Riau, 2(2), 1-14.

Fahmi, I. (2014). Analisis Laporan Keuangan. Bandung: Alfabeta.

Ghozali, I. (2013). Aplikasi Analisis Multivariat dengan Program IBM SPSS 23 (8th ed.). Semarang: Badan Penerbit Universitas Diponegoro.

Harahap, S. S. (2008). Analisis Kritis atas Laporan Keuangan. Jakarta: PT. Raja Grafindo Persada.

Hery. (2016). Financial Ratio for Business. Jakarta: PT. Grasindo.

Indayani., \& Yahya, M. N. (2013). Pengaruh Posisi Kas, Rasio Utang Terhadap Ekuitas, dan Potensi Pertumbuhan Terhadap Rasio Pembagian Dividen Pada Perusahaan Manufaktur yang Terdaftar di BEI. Jurnal Etikonomi, 12(1), 45-60.

Indriyani, E. (2017). Pengaruh Ukuran Perusahaan dan Profitabilitas Terhadap Nilai Perusahaan. Akuntabilitas: Jurnal Ilmu Ekonomi, 10(2), 333-348. https://doi.org/10.15408/akt.v10i2.4649

Jayanti, F. D. (2018). Pengaruh Profitabilitas, Struktur Modal, Likuiditas, Dan Ukuran Perusahaan Terhadap Nilai Perusahaan. Jurnal Bingkai Ekonomi, 3(2), 34-44.

Kasmir. (2012). Analisis Laporan Keuangan. Jakarta: PT. Raja Grafindo Persada.

Kholisoh, L., \& Agung, R. S. (2011). Pengaruh Pengumuman Dividen Terhadap Perubahan Harga Saham: Studi Di Bursa Efek Jakarta (BEJ). Jurnal Ekonomi Dan Kewirausahaan, 7(14), 39-52.

Khumairoh., Kalbuana, N., \& Mulyati, H. (2016). Pengaruh Leverage, Profitabilitas, dan Ukuran Perusahaan Terhadap Nilai Perusahaan. Seminar Nasional Dan The 3rd Call for Syariah Paper, 71-81.

Mery, K. N., Zulbahridar., \& Kurnia, P. (2017). Pengaruh Likuiditas, Leverage, dan Profitabilitas Terhadap Nilai Perusahaan Dengan Kebijakan Dividen Sebagai Variabel Moderasi Pada Perusahaan Pertambangan yang Terdaftar di Bursa Efek Indonesia Tahun 2011-2014. Jurnal Online Mahasiswa (JOM) Bidang Akuntansi, 4(1), 20002014.

Oktarima, B. (2017). Pengaruh Profitabilitas, Likuiditas, dan Struktur Modal Terhadap Nilai Perusahaan. Jurnal Sekuritas, 1(1), 98-107. 
Pasaribu, A. M. (2015). Pengaruh Kualitas Auditor, Likuiditas, Solvabilitas, dan Profitabilitas Terhadap Opini Audit Going Concern Pada Sub Sektor Makanan dan Minuman Yang Terdaftar di Bursa Efek Indonesia. Jurnal Review Akuntnasi Dan Keuangan, 6(2), 8092.

Putra, A. A. G. T. D., \& Wirakusuma, M. G. (2017). Pengaruh Corporate Social Responsibility Disclosure Terhadap Nilai Perusahaan Dengan Kepemilikan Asing Sebagai Variabel Pemoderasi. E-Jurnal Akuntansi Universitas Udayana, 19(3), 17191746.

Putra, A. N. D. A., \& Lestari, P. V. (2016). Pengaruh Kebijakan Dividen, Likuiditas, Profitabilitas dan Ukuran Perusahaan Terhadap Nilai Perusahaan. E-Jurnal Manajemen Universitas Udayana, 5(7), 4044.

Putri, M. T., \& Ibrahim, M. (2017). Pengaruh Profitabilitas dan Keputusan Investasi Terhadap Nilai Perusahaan Pulp \& Paper Yang Terdaftar di Bursa Efek Indonesia. Jurnal On Mahasiswa (JOM) FISIP Universitas Riau, 4(2), 1-7.

Rochmah, S. A., \& Fitria, A. (2017). Pengaruh Kinerja Keuangan Terhadap Nilai Perusahaan: Kebijakan Dividen Sebagai Variabel Moderating. Jurnal Ilmu dan Riset Akuntansi, 6(3), 998-1017.

Rudangga, I. G. N. G., \& Sudiarta, G. M. (2016). Pengaruh Ukuran Perusahaan Leverage, dan Profitabilitas Terhadap Nilai Perusahaan. E-Jurnal Manajemen Universitas Udayana, 5(7), 4394-4422.

Sitanggang. (2012). Manajemen Keuangan Perusahaan Dilengkapi Soal dan Penyelesaiannya. Jakarta: Mitra Wacana.

Sudana, I. M. (2011). Manajemen Keuangan Perusahaan: Teori dan Praktik. Jakarta: Erlangga.

Sugiyono. (2014). Metode Penelitian Bisnis (Pendekatan Kuantitatif, Kualitatif, dan R\&D). Bandung: CV Alfabeta.

Sunjoyo, R., Carolina, V., Magdalena, N., \& Kurniawan, A. (2013). Aplikasi SPSS untuk Smart Riset. Bandung: Alfa Beta.

Susilaningrum, C. (2016). Pengaruh Return On Assets, Rasio Likuiditas, dan Rasio Solvabilitas Terhadap Nilai Perusahaan Dengan Pengungkapan Corporate Social Responsibility (CSR) Sebagai Variabel Moderasi. Jurnal Profita, 4(8), 1-17. 